\title{
A Versatile Annulation Route to Primary-Amino-Substituted Naphthyridine Esters
}

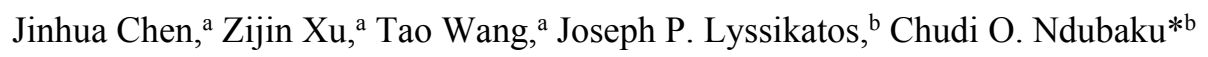 \\ a Wuxi AppTec, 288 Fute Zhong Road, Waigaoqiao Free Trade Zone, Shanghai 200131, P. R. of China \\ b Discovery Chemistry, Genentech, Inc., 1 DNA Way, South San Francisco, CA 94080, USA \\ Fax +1(650)7424943; E-mail: chudin@gene.com
}

Received: 16.08.2013; Accepted after revision: 09.10.2013

\begin{abstract}
A straightforward four-step synthesis of primary-aminosubstituted naphthyridine esters from commercially available cyanopyridines was described. The route makes use of a condensation reaction between pyridinyl acetates with $N, N$-dimethylformamide dimethylacetal (DMF-DMA) to form ortho-cyano vinylogous carbamates. These intermediates can undergo facile cyclization with ammonium acetate in acetic acid to generate the corresponding naphthyridine esters in good synthetic yields. The synthesis of primary-amino-substituted 7-azaquinoxaline was also described.
\end{abstract}

Key words: naphthyridine, annulation, vinylogous carbamates, heterocycles, scaffold

The naphthyridine scaffold has found some utility as a template in medicinally active compounds. ${ }^{1}$ It has been shown to be a rigid replacement for diketo acids, comprising the central architecture of antiviral drug L-870,810 (1) and the antibiotic trovafloxacin (2) (Figure 1). ${ }^{2,3}$ In addition, it can serve as a suitable core for phosphodiesterase4 inhibitors such as NVP-ABE171 (3) ${ }^{4}$ as well as several known kinase inhibitors.

As a part of a program that sought to utilize various regioisomeric primary-amino-substituted naphthyridine esters 4, we required a facile route for the preparation of such compounds. Previously, this type of heterocycle had been prepared in lengthy and low-yielding chemical routes. ${ }^{5,6}$ We sought instead to develop a more concise and general strategy for preparing various naphthyridine isomers in a controlled fashion. Herein we report one such approach that proved to be useful for the construction of several primary-amino-substituted naphthyridine esters (Scheme 1). The key transformation in this approach is the annulation of 2-cyano-substituted vinylogous carbamates $\mathbf{1 0}$ with ammonium acetate under mildly acidic conditions. The method described makes use of readily available halogenated azine heterocycles (pyridines or pyrazine) bearing an ortho-substituted nitrile group $\mathbf{5}$. These can be transformed into the bicyclic ring makeup of the naphthyridines in a few iterative steps. Pirnat et al. have previously reported a similar approach, although their method was only demonstrated to work for 2,7-naphthyridin-1-ones. ${ }^{7}$

SYNLETT 2014, 25, 0089-0092

Advanced online publication: 02.12.2013

DOI: 10.1055/s-0033-1340111; Art ID: ST-2013-R0792-L

C Georg Thieme Verlag Stuttgart · New York

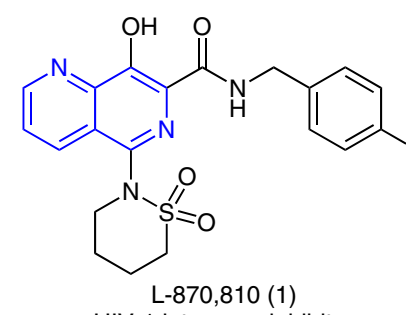

HIV-1 integrase inhibitor

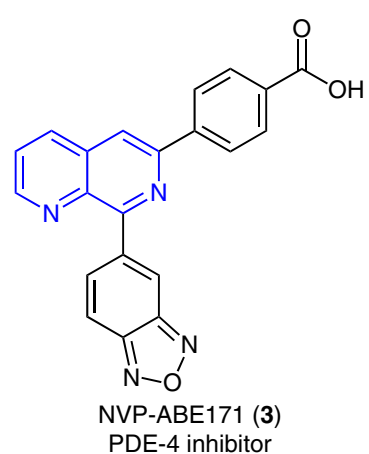

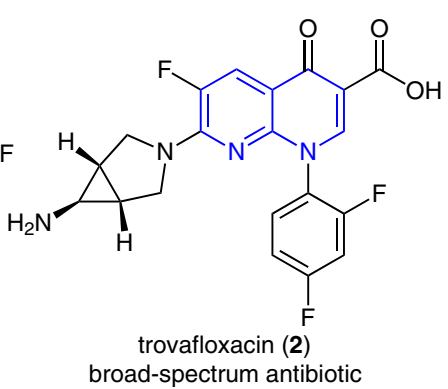

broad-spectrum antibiotic

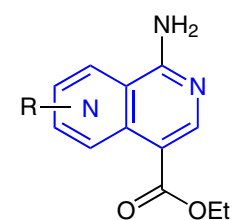

4

this work
Figure 1 Examples of naphthyridine-containing compounds

In one example, $\mathrm{S}_{\mathrm{N}} \mathrm{Ar}$ reaction of 3-cyano-4-fluoropyridine (5a) with the sodium salt of diethyl malonate was used to generate $7 \mathbf{a}$ (Scheme 1). Krapcho decarboxylation of 7a provided the pyridinyl acetate 8a. Condensation with DMF-DMA then generates the cyclization precursor 10a. With 10a in hand, three screening conditions were attempted to effect the transformation to the naphthyridine ester 4a (Table 1). We observed that subjecting the substrate 10a to an ammonia solution in water-ethanol (10:1) resulted only in a minimal amount of the naphthyridine product 4a being generated (Table 1, entry 1 ). Next, we found that using ammonium chloride and hydrochloric acid, a strong acid, resulted predominantly in undesired nitrile-group hydrolysis (Table 1, entry 2). Finally, employing ammonium acetate and a milder acid (acetic acid) at slightly elevated temperatures yielded $60-70 \%$ of the desired product 4a (Table 1, entry 3).

Encouraged by the latter result, the substrate scope was then examined (Table 2). A variety of commercially available regioisomeric halogenated pyridines were employed in the two-step conversion into the precursor pyridinyl acetates $\mathbf{8 b}-\mathbf{e}$. As exemplified by $\mathbf{8 f}$, this methodology was also applicable to the synthesis of pyrazine-derived ana- 


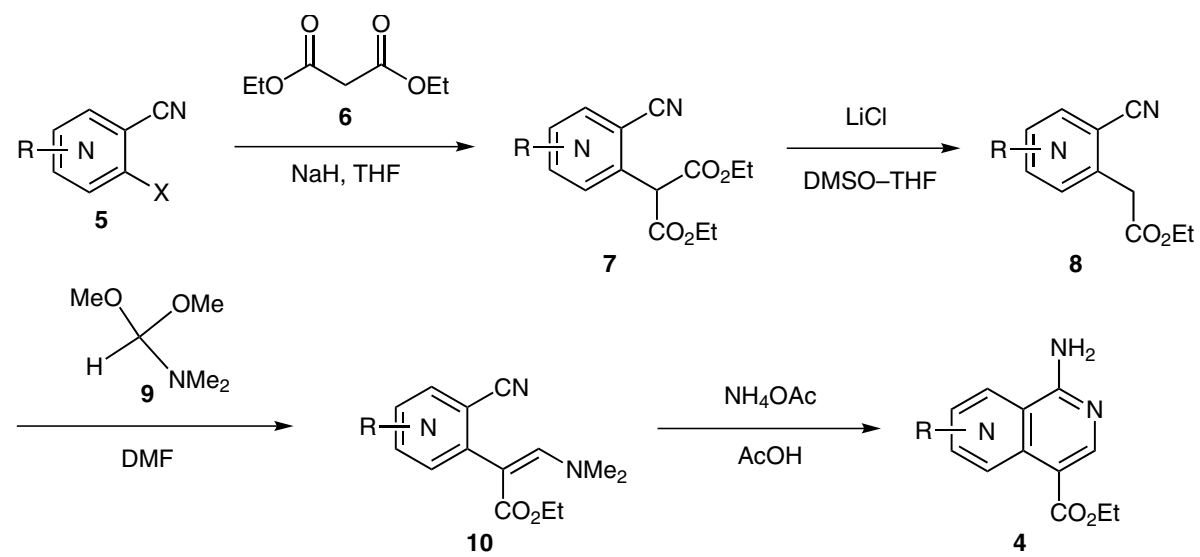

Scheme 1 General synthetic route for the preparation of naphthyridine isomers

Table 1 Reaction Screening for Effective Cyclization Conditions<smiles>CCOC(=O)c1ccncc1C#N</smiles>

$10 \mathrm{a}$

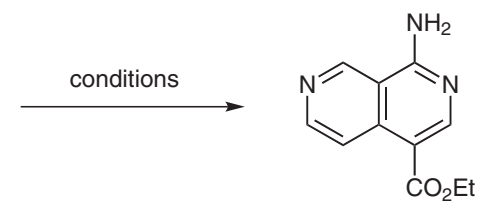

$4 a$

\begin{tabular}{lll}
\hline Entry & Conditions & Results \\
\hline 1 & $\mathrm{NH}_{3}, \mathrm{H}_{2} \mathrm{O}-\mathrm{EtOH}(10: 1)$, reflux & $<5 \%$ desired product + complex mixture of undesired products \\
2 & $\mathrm{NH}_{4} \mathrm{Cl}, \mathrm{HCl}, \mathrm{EtOH}$, reflux & $0 \%$ product; extensive nitrile hydrolysis to amide \\
3 & $\mathrm{NH}_{4} \mathrm{OAc}, \mathrm{AcOH}(1: 5), 80-100{ }^{\circ} \mathrm{C}$ & $60-70 \%$ yield of $4 \mathbf{a}$ \\
\hline
\end{tabular}

logues. As with the screening substrate 10a, the conditions for the annulation step using ammonium acetate in hot acetic acid were applied to each of the vinylogous carbamate substrates in the final step of the transformation. All substrates were converted in reasonable isolated yields to the respective naphthyridines (or 7-azaquinoxaline, Table 2, entry 6) from the corresponding acetate intermediate. Even the electron-poor substrate bearing a trifluoromethyl group was successful in generating the naphthyridine in 16\% yield over two steps (Table 2, entry
5). Unfortunately, an electron-rich methoxy-substituted precursor could not be prepared as the $\mathrm{S}_{\mathrm{N}} \mathrm{Ar}$ reaction proved unsuccessful.

Two plausible reaction mechanisms for the annulation step are shown in Scheme 2. Under the acidic reaction conditions employed, ammonium acetate can add to the nitrile to form an incipient amidine 11. This compound can then undergo facile conjugate cyclization to generate the corresponding naphthyridine heterocycle 12. Finally, extrusion of dimethylamine proceeds to furnish the de-

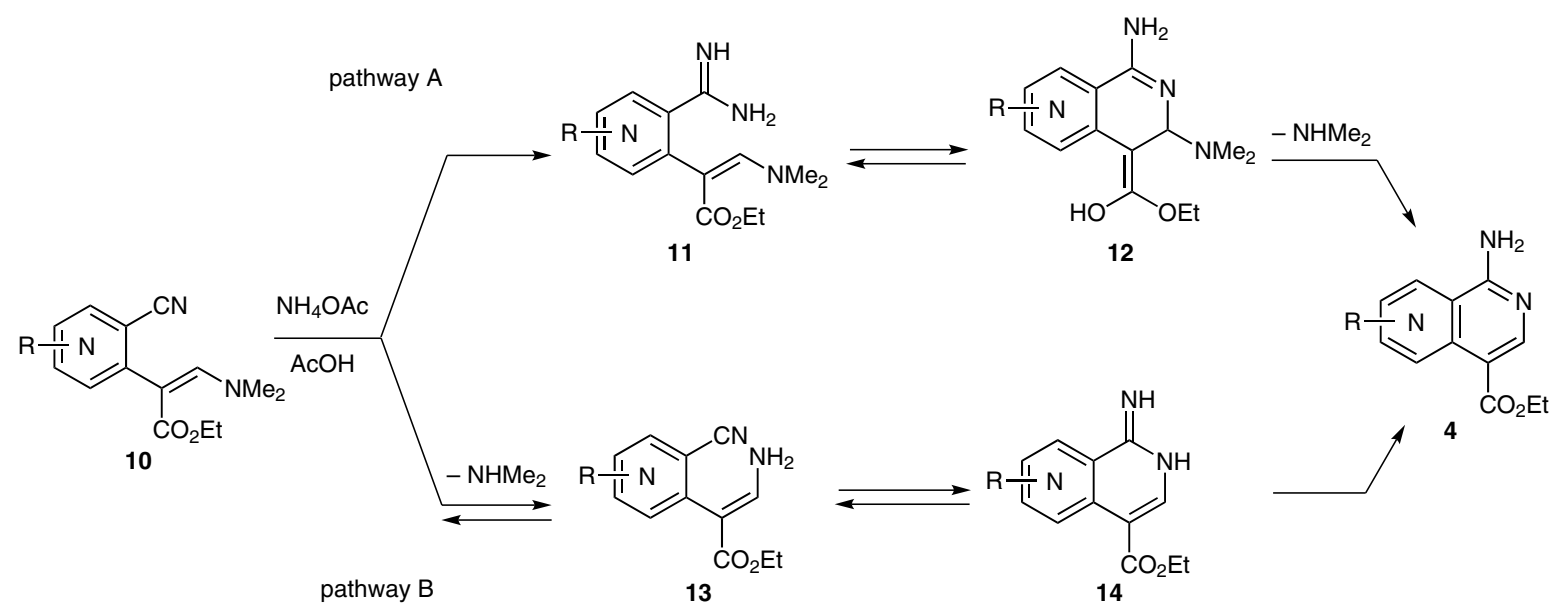

Scheme 2 Proposed reaction mechanisms for cyclization leading to naphthyridine ester 4 
Table 2 Isolated Yields for Two-Step Annulation from Pyridinyl Acetate to Naphthyridines
$8 \mathbf{a}$<smiles>CCOC(=O)Cc1cccnc1C#N</smiles>

8b<smiles>CCOC(=O)Cc1cnccc1C#N</smiles>

$8 c$<smiles>CCOC(=O)Cc1ncccc1C#N</smiles>

8d<smiles>CCOCc1nccc(C(F)(F)F)c1C#N</smiles>

$8 \mathrm{e}$<smiles>CCOC(=O)Cc1nccnc1C#N</smiles>

$8 f$

\section{Entry Substrate<smiles>CCOC(=O)Cc1ccncc1C#N</smiles>

Product<smiles>CCOC(=O)c1cnc(N)c2cnccc12</smiles>

$4 a$<smiles>CCOC(=O)c1cnc(N)c2ncccc12</smiles>

$4 b$<smiles>CCOC(=O)c1cnc(N)c2ccncc12</smiles>

$4 c$<smiles>CCOC(=O)c1cnc(N)c2cccnc12</smiles>

4d<smiles>CCOC(=O)c1cnc(N)c2c(C(F)(F)F)ccnc12</smiles>

$4 e$<smiles>CCOC(=O)c1cnc(N)c2nccnc12</smiles>

${ }^{a}$ Final two steps.

sired product 4 (pathway A). Alternatively, early expulsion of dimethylamine can lead to $\mathbf{1 3}$, which upon rapid cyclization onto the pendant nitrile provides 14 . This intermediate can then tautomerize to generate the desired product 4 (pathway $B$ ). We speculate that pathway $B$ is more feasible because formation of the amidine $\mathbf{1 1}$ in pathway A is an energetically disfavored process. Moreover, in the work reported by Pirnat et al., ${ }^{7}$ they failed to observe any amidines among the various intermediates that were isolated.

In summary, a unified approach to the preparation of primary-amino-substituted naphthyridines as well as a 7-azaquinoxaline was described. By making use of easily accessible 2-halocyanopyridines, these various naphthyridines were derived in a four-step sequence that provides the desired products in synthetically useful yields. As a demonstration of the broader utility of this method, we were able to prepare an entire set of regioisomeric primary amino naphthyridine esters. Further application of this method in a more complex setting such as the synthesis of active pharmaceuticals is currently under way.

Diethyl 2-(3-Cyanopyridin-4-yl)malonate (7a)

To a stirred solution of $\mathrm{NaH}(289 \mathrm{mg}, 7.22 \mathrm{mmol}, 60 \%)$ in THF (5 $\mathrm{mL})$ was added diethyl malonate $(1.16 \mathrm{~g}, 7.22 \mathrm{mmol})$ in THF $(5$ $\mathrm{mL}$ ) dropwise at $0{ }^{\circ} \mathrm{C}$ under $\mathrm{N}_{2}$ atmosphere. After the reaction mixture was stirred at $0{ }^{\circ} \mathrm{C}$ for $10 \mathrm{~min}$, compound $\mathbf{5 a}(500 \mathrm{mg}, 3.61$ $\mathrm{mmol})$ in THF $(5 \mathrm{~mL})$ was added. The reaction mixture was heated at reflux for $4 \mathrm{~h}$ under $\mathrm{N}_{2}$ and was quenched with aq $\mathrm{NH}_{4} \mathrm{Cl}(20 \mathrm{~mL})$ and extracted with EtOAc $(3 \times 20 \mathrm{~mL})$. The organic layer was washed with brine $(2 \times 10 \mathrm{~mL})$, dried over $\mathrm{Na}_{2} \mathrm{SO}_{4}$, and concentrated to give 7a as a crude product, which was used for the next step without further purification.

\section{Ethyl 2-(3-Cyanopyridin-4-yl)acetate (8a)}

To a solution of crude compound $7 \mathrm{a}(1.0 \mathrm{~g}, 3.61 \mathrm{mmol})$ in DMSO $(30 \mathrm{~mL})$ were added $\mathrm{H}_{2} \mathrm{O}(1 \mathrm{~mL})$ and $\mathrm{LiCl}(459 \mathrm{mg}, 10.82 \mathrm{mmol})$, and the resulting mixture was stirred at $100{ }^{\circ} \mathrm{C}$ overnight. After the reaction mixture was cooled to r.t., it was extracted with EtOAc (3 $\times 20 \mathrm{~mL})$, washed with brine $(10 \times 2 \mathrm{~mL})$, dried over $\mathrm{Na}_{2} \mathrm{SO}_{4}$, and concentrated. The residue was purified by column chromatography $(\mathrm{PE}-\mathrm{EtOAc}=8: 1)$ to give $8 \mathbf{a}$ as white solid $(300 \mathrm{mg}, 43 \%$ over two steps). ${ }^{1} \mathrm{H}$ NMR $\left(400 \mathrm{MHz}, \mathrm{DMSO}-d_{6}\right): \delta=8.82(\mathrm{~s}, 1 \mathrm{H}), 8.70(\mathrm{~d}$, $J=6.4 \mathrm{~Hz}, 1 \mathrm{H}), 7.37(\mathrm{~d}, J=6.4 \mathrm{~Hz}, 1 \mathrm{H}), 4.19(\mathrm{q}, 2 \mathrm{H}), 1.24(\mathrm{t}, 3 \mathrm{H})$.

\section{Ethyl 2-(3-Cyanopyridin-4-yl)-3-(dimethylamino)acrylate}

(10a)

A solution of compound $8 \mathbf{a}(100 \mathrm{mg}, 0.526 \mathrm{mmol})$ and DMF-DMA $(157 \mathrm{mg}, 1.31 \mathrm{~mol})$ in DMF $(5 \mathrm{~mL})$ was heated at $80^{\circ} \mathrm{C}$ overnight. The mixture was evaporated to dryness and carried on to the next step without further purification.

Ethyl 1-Amino-2,7-naphthyridine-4-carboxylate (4a)

A mixture of crude compound 10a from the previous step $(150 \mathrm{mg})$ and $\mathrm{NH}_{4} \mathrm{OAc}(1.0 \mathrm{~g}, 13.15 \mathrm{mmol})$ in $\mathrm{AcOH}(5 \mathrm{~mL})$ was heated at $80-100{ }^{\circ} \mathrm{C}$ overnight. The mixture was cooled to ambient temperature and poured into ice water. The mixture was extracted with EtOAc $(3 \times 20 \mathrm{~mL})$. The combined organic phase was concentrated to give the crude product, which was purified by preparative TLC $(\mathrm{PE}-\mathrm{EtOAc}=1: 1)$ to give the desired product $4 \mathrm{a}(50 \mathrm{mg}, 43 \%$ over two steps). ${ }^{1} \mathrm{H}$ NMR (400 MHz, DMSO- $\left.d_{6}\right): \delta=9.19$ (s, $\left.1 \mathrm{H}\right), 8.87$ $(\mathrm{s}, 1 \mathrm{H}), 8.75(\mathrm{~d}, J=6.0 \mathrm{~Hz}, 1 \mathrm{H}), 8.68(\mathrm{~d}, J=6.0 \mathrm{~Hz}, 1 \mathrm{H}), 5.78(\mathrm{br}$, $2 \mathrm{H}), 4.35$ (q, $2 \mathrm{H}), 1.37$ (m, $J=6.8 \mathrm{~Hz}, 1 \mathrm{H}), 1.20(\mathrm{t}, 3 \mathrm{H})$.

\section{Acknowledgment}

The authors thank Drs. Charles Ding and Kevin Chen (Wuxi) as well as Dr. Bing-Yan Zhu (Genentech) for helpful discussions during the course of this work.

\section{References}

(1) The Naphthyridines, In The Chemistry of Heterocyclic Compounds; Vol. 63; Brown, D. J.; Ellman, J. A.; Taylor, E. C., Eds.; J. Wiley and Sons: Hoboken, 2007.

(2) Hazuda, D. J.; Anthony, N. J.; Gomez, R. P.; Jolly, S. M.; Wai, J. S.; Zhuang, L.; Fisher, T. E.; Embrey, M.; Guare, J. P.; Egbertson, M. S.; Vacca, J. P.; Huff, J. R.; Felock, P. J.; 
Witmer, M. V.; Stillmock, K. A.; Danovich, R.; Grobler, J.; Miller, M. D.; Espeseth, A. S.; Jin, L.; Chen, I.-W.; Lin, J. H.; Kassahun, K.; Ellis, J. D.; Wong, B. K.; Xu, W.; Pearson, P. G.; Schleif, W. A.; Cortese, R.; Emini, E.; Summa, V.; Holloway, M. K.; Young, S. D. Proc. Natl. Acad. Sci. U.S.A. 2004, 101, 11233 .

(3) Haria, M.; Lamb, H. M. Drugs 1997, 54, 435.

(4) Press, N. J.; Taylor, R. J.; Fullerton, J. D. J. Med. Chem. 2012, 55, 7472 .

(5) Some existing methods for the preparation of primaryamino-substituted naphthyridines: (a) Albert, A.; Hampton,
A. J. Chem. Soc. 1952, 4985. (b) Van Den Haak, H. J. W.; Van Der Plas, H. C.; Veldhuizen, B. V. J. Org. Chem. 1982, 46, 2134. (c) Alhaique, F.; Riccieri, F. M.; Santucci, E. Tetrahedron Lett. 1975, 173.

(6) (a) Fleury, J.-P.; Desbois, M. J. Heterocycl. Chem. 1978, 15, 1005. (b) Van Den Haak, H. J. W.; Van Der Plas, H. C.; Veldhuizen, B. V. J. Heterocycl. Chem. 1981, 18, 1349.

(7) Pirnat, K.; Šimunek, P.; Uršič, U.; Bezenšek, J.; Grošelj, U. ARKIVOC 2011, (vi), 120. 